Article

\title{
Investigation into the Presence of Symbiodiniaceae in Antipatharians (Black Corals)
}

\author{
Erika Gress ${ }^{1,2,3, * \mathbb{D}}$, Igor Eeckhaut ${ }^{2,4}$, Mathilde Godefroid ${ }^{5}\left(\mathbb{D}\right.$, Philippe Dubois ${ }^{5}$, Jonathan Richir 6 \\ and Lucas Terrana ${ }^{2}$
}

check for updates

Citation: Gress, E.; Eeckhaut, I.; Godefroid, M.; Dubois, P.; Richir, J.; Terrana, L. Investigation into the Presence of Symbiodiniaceae in Antipatharians (Black Corals). Oceans 2021, 2, 772-784. https://doi.org/ 10.3390 /oceans 2040044

Academic Editors: Rupert Ormond, Peter Schupp, Ronald Osinga and Michael W. Lomas

Received: 29 October 2020

Accepted: 18 November 2021

Published: 25 November 2021

Publisher's Note: MDPI stays neutral with regard to jurisdictional claims in published maps and institutional affiliations.

Copyright: (c) 2021 by the authors. Licensee MDPI, Basel, Switzerland. This article is an open access article distributed under the terms and conditions of the Creative Commons Attribution (CC BY) license (https:// creativecommons.org/licenses/by/ $4.0 /)$.
1 ARC Centre of Excellence for Coral Reef Studies, James Cook University, Townsville 4811, Australia

2 Biology of Marine Organisms and Biomimetics, University of Mons, 7000 Mons, Belgium; Igor.EECKHAUT@umons.ac.be (I.E.); lucas.terrana@gmail.com (L.T.)

3 Nekton Foundation, Oxford OX5 1PF, UK

4 Institute of Halieutics and Marine Sciences, University of Toliara, Toliara 601, Madagascar

Marine Biology Laboratory, Free University of Brussels, 1050 Brussels, Belgium; mathilde.an.godefroid@ulb.ac.be (M.G.); phdubois@ulb.ac.be (P.D.)

6 Chemical Oceanography Unit, FOCUS, University of Liege, 4000 Liege, Belgium; jonathan.richir@uliege.be

* Correspondence: gresserika@gmail.com or erika@nektonmission.org

\begin{abstract}
Here, we report a new broad approach to investigating the presence and density of Symbiodiniaceae cells in corals of the order Antipatharia subclass Hexacorallia, commonly known as black corals. Antipatharians are understudied ecosystem engineers of shallow ( $<30 \mathrm{~m}$ depth), mesophotic (30-150 m) and deep-sea (>200 m) reefs. They provide habitat to numerous organisms, enhancing and supporting coral reef biodiversity globally. Nonetheless, little biological and ecological information exists on antipatharians, including the extent to which global change disturbances are threatening their health. The previous assumption that they were exempted from threats related to the phenomenon known as bleaching was challenged by the recent findings of high densities of dinoflagellates within three antipatharian colonies. Further studies were thus necessary to investigate the broader uniformity of these findings. Here we report results of an integrated methodology combining microscopy and molecular techniques to investigate the presence and estimate the density of Symbiodiniaceae cells within two antipatharians species-Cupressopathes abies and Stichopathes maldivensis-from both shallow and mesophotic reefs of SW Madagascar. We found that Symbiodiniaceae-like cells were present within samples of both species collected from both shallow and mesophotic reefs, although the overall cell density was very low $\left(0-4\right.$ cell $\left.\mathrm{mm}^{-3}\right)$. These findings suggest that presence or high abundance of Symbiodiniaceae is not characteristic of all antipatharians, which is relevant considering the bleaching phenomenon affecting other corals. However, the possibility of higher densities of dinoflagellates in other antipatharians or in colonies exposed to higher light irradiance deserves further investigation.
\end{abstract}

Keywords: coral reefs; symbiotic algae; dinoflagellates; Madagascar; symbiosis

\section{Introduction}

Coral reefs are both among the most biodiverse of marine habitats and among the most productive ecosystems on Earth [1]. However, most of our information 'about them is based on our knowledge of shallow reefs ( $<30 \mathrm{~m}$ depth). Light-dependent reefs can thrive in deeper waters though. Mesophotic coral ecosystems (MCEs) are light-dependent coral reefs found typically from 30 to $150 \mathrm{~m}$ in tropical and subtropical regions [2]. Hereinafter, MCEs are also referred to as 'mesophotic reefs' for the ease of the reader, a phrase considered analogous with the term 'shallow reefs'. Mesophotic reefs have been estimated to represent about $80 \%$ of potential coral reef habitat by area worldwide; however, we know little about them compared to shallow reefs [3]. Scleractinians (hard corals) are present in MCEs, but to 
a much lesser extent than in shallow reefs [3-5]. Instead, antipatharians, octocorals, sponges and macroalgae provide most of the available habitat structure at these depths [3-5].

The order Antipatharia (subclass Hexacorallia) consists of seven families and around 270 species [6,7]. These corals occur in most oceans at depths ranging from 2 to $8900 \mathrm{~m}$, generally favouring strong currents and low-light environments [8,9]. Antipatharians do not produce a calcium carbonate skeleton; instead, the thorny axial skeleton is composed of a proteinaceous complex called antipathin $[10,11]$. It has been suggested that antipatharians tend to increase in diversity and abundance with depth, reaching a peak at mesophotic depths (30-150 m) [12]. Nonetheless, dense aggregations of antipatharians have also been observed in shallow ( $<30 \mathrm{~m}$ depth) clear water environments [13,14], Gress pers. obs. Further, they are important habitat-providing corals with which an array of marine fauna associates $[9,13,15-18]$. For instance, in the Philippines, the average density of invertebrate macrofauna associated with antipatharians ranged from 82 to 8313 individuals $\mathrm{m}^{-2}$ [14]. Thus, antipatharians can be considered ecosystem engineers supporting and enhancing marine biodiversity at shallow, mesophotic and deep-sea depths.

However, limited studies have evaluated their current condition under increasing threats, such as those associated with global warming. In the closely related Hexacorallian order of scleractinia, global warming has led to extensive mortality due to temperaturerelated coral bleaching. Bleaching is the consequence of a disturbance of the symbiotic relationship between dinoflagellates and scleractinians on both shallow and mesophotic reefs as a result of climate change- a causal relationship that is well established [19-22]. Nevertheless, our understanding of the physiological mechanisms underlying the endosymbiotic association between dinoflagellates and their cnidarian host has been frequently revised, and this relationship is still not fully understood. It now appears that four of the seven genera of Symbiodiniaceae are found in symbioses with scleractinian corals (Symbiodinium, Breviolum, Cladocopium and Durusdinium) [23,24]. The translocation of photosynthetically fixed carbon from the symbiont to the host is considered the best-known aspect of the coral-algae symbiosis. However, the amount of photosynthetic carbon translocated to the host and the identity of the compounds are not fully known [25].

In the coral-algae symbiotic association, Symbiodiniaceae harvest sunlight for photosynthesis and dissipate excess energy so as to prevent light-induced oxidative stress [26-28]. Under ambient conditions (i.e., not heat and light-stressed), Symbiodiniaceae absorbs light that can be (1) used to drive photochemistry, (2) re-emitted as fluorescence, (3) dissipated as heat or (4) decayed via the chlorophyll triplet state [26-29]. Experiments have shown that Symbiodiniaceae in scleractinians, under typical irradiances at shallow coral reefs $\left(640 \mu \mathrm{mol}\right.$ photons $\left.\mathrm{m}^{-2} \mathrm{~s}^{-1}\right)$, dissipate $96 \%$ of the energy and use only $4 \%$ of the absorbed light energy for photosynthesis [26]. However, over prolonged periods of water temperature alterations, the invertebrate host needs to lower the number of its symbionts because the oxidative stress, which results from the production and accumulation of reactive oxygen species (ROS), can damage lipids, proteins and DNA [27,30]. When corals reduce the number of their symbionts, the main source of ROS production is removed, although the coral host itself may also produce ROS as a result of light and temperature [27]. Oxidative stress on corals results in a lack or low number of dinoflagellates and their photosynthetic pigments, an effect known as 'coral bleaching'. Three potential mechanisms have been suggested for the regulation of symbiont numbers under such stressful conditions: (i) expulsion of excess symbionts; (ii) degradation of symbionts by host cells; and (iii) inhibition of symbiont cell growth and division controlled by the $\mathrm{pH}$ of the host cell $[25,31]$.

The earliest suggestion of dinoflagellates being present in antipatharian tissues comes from the Report on the Antipatharia collected by H.M.S. Challenger by Brook [32]. A few years later, in a report on The Antipatharia of the Siboga Expedition, van Pesch [33] documented six species containing what he referred to as 'symbiotic Algae' ranging from 7-10 $\mu \mathrm{m}$ in diameter present in the gastrodermis. Significantly, he reported observing these cells in only six out of the thirty species he examined [33]). With no more empirical studies 
or reports for many decades and given antipatharians ability to thrive at abyssal depths and in low-light environments, they were assumed to lack Symbiodiniaceae, which is commonly referred to as 'being azooxanthellate' [8,34]. Moreover, a few later reports using molecular techniques did not find dinoflagellates in the antipatharian species examined. For instance, after intense morphological studies, dinoflagellates were reported absent in Antipathes grandis VERRILL, 1928, from Hawaii [35]. Likewise, dinoflagellate-specific primers and spectrophotometric methods that detect dinoflagellate chlorophyll absorbance patterns did not reveal any found microalgae in the species Stichopathes luetkeni (BROOK, 1889) (formerly called Cirrhipathes lutkeni) [36].

In contrast, in accordance with the early historical suggestions, two more recent studies have confirmed the presence of Symbiodiniaceae in various antipatharian species. A histological analysis of 14 antipatharian species collected from a depth between 10 and $396 \mathrm{~m}$ from

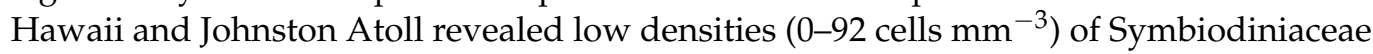
cells inside antipatharian gastrodermal tissues, suggesting that the dinoflagellates are endosymbiotic [34]. Additionally, dinoflagellates sequences retrieved from the antipatharians confirmed the presence of Symbiodiniaceae in the genera Cladocopium, Gerakladium and Durusdinium. However, it was concluded that the endosymbiotic dinoflagellates had no significant role in the 'nutrition' of the species examined and suggested more research to determine whether the association might be parasitic [34]. The conclusion was based on the low density of microalgae cells within the antipatharians and their presence in colonies at depths where light penetration does not enable photosynthesis. They did not find any pattern in the types of Symbiodiniaceae present in the different antipatharian species; therefore, they suggested that endosymbiont acquisition might occur opportunistically and not be host-specific. In another recent study conducted on a single species of the genus Cirrhipathes from Indonesia, two colonies were sampled at $38 \mathrm{~m}$ and one at $15 \mathrm{~m}$ and evidence of abundant $\left(\sim 10^{7}\right.$ cells $\left.\mathrm{cm}^{-2}\right)$ Symbiodiniaceae cells in the gastrodermis of the corals was found [37]. Among these, the authors identified two genera-Cladocopium and Gerakladium - the latter commonly found in association with clinoid sponges. They concluded that a mutualistic endosymbiosis existed based on the presence of the dinoflagellates inside the antipatharian gastrodermis and a symbiosome surrounding the microalgal cell, combined with evidence of its division inside the host [37]. These findings led us to reconsider our view of the vulnerability of antipatharians to global change and prompted us to further investigate the occurrence of dinoflagellate symbionts in antipatharian species.

Most lineages in the subclass Hexacorallia are believed to have evolved photosymbioses independently [38], with the order Antipatharia being one of the exceptions until evidence of antipatharian species hosting dinoflagellates inside the coral gastrodermis was found $[34,37]$. However, these two studies presented two contrasting conclusions. In one case, it was concluded that the presence of the Symbiodiniaceae was opportunistic, and in the other, it was concluded that a mutualistic endosymbiosis existed. Those conclusions were based on the presence and abundance of the Symbiodiniaceae cells and their location in the host tissue, although from a very limited number of specimens. The present study was therefore undertaken with the objective of gaining further insight into the possibility of antipatharians hosting high abundances of dinoflagellates, expanding the geographic range of the species studied and the number of colonies examined. We used an integrated methodological approach, combining both microscopy and molecular techniques to investigate the presence, abundance, location and identity of Symbiodiniaceae in two antipatharian species-Cupressopathes abies (LINNAEUS, 1758) and Stichopathes maldivensis COOPER, 1903. Our samples represent two different morphologies and were collected from both shallow and mesophotic reefs in SW Madagascar.

\section{Materials and Methods}

\subsection{Site Description}

Sample collection took place near the Great Reef of Toliara (GRT), in SW Madagascar, at a barrier reef almost $20 \mathrm{~km}$ long and $2 \mathrm{~km}$ wide, bordered by freshwater rivers at 
its northern (Fiherenana River) and southern (Onilahy River) extremities (Figure 1a). Coral communities, including scleractinians and antipatharians, were first documented in shallow ( $<30 \mathrm{~m}$ depth) and mesophotic reef (at depths between $35 \mathrm{~m}$ and $55 \mathrm{~m}$ ) areas in the 1970s [39]. More recent studies have documented severe reef degradation due to fisheries, pollution and heavy sedimentation derived from the adjacent rivers [40-42], as well as coral bleaching episodes [43]. Antipatharian samples were collected in NovemberDecember 2018 on shallow (20 m depth, $23^{\circ} 20.978^{\prime} \mathrm{S}, 43^{\circ} 36.885^{\prime} \mathrm{E}$-Site 1 ) and mesophotic (40 m depth, $23^{\circ} 21.345^{\prime} \mathrm{S}, 43^{\circ} 36.348^{\prime} \mathrm{E}$-Site 2 ) reefs (Figure 1a) during a non-bleaching episode. Figure $1 \mathrm{~b}$ shows the annual median for 2018 of the diffuse attenuation coefficient for downwelling irradiance at $490 \mathrm{~nm}^{-1} \mathrm{~m}^{-1}\left(\mathrm{~K}_{\mathrm{d}} 490\right)$ over the wider region as obtained from satellite data (MODIS-Aqua), a proxy for water turbidity [44].
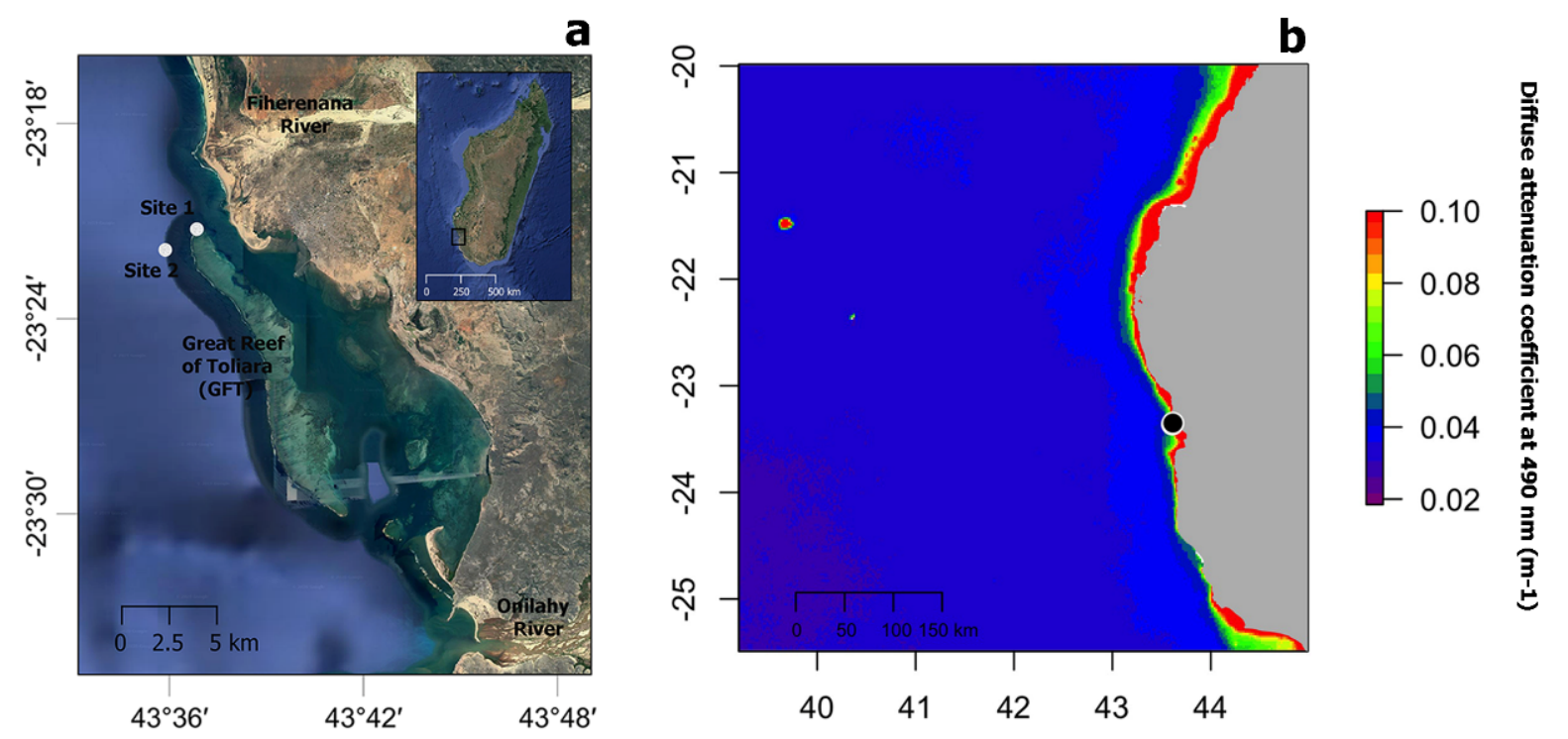

Figure 1. (a) Map showing the location of study sites 1 and 2 (white circles) near the Great Reef of Toliara (GRT) in SW

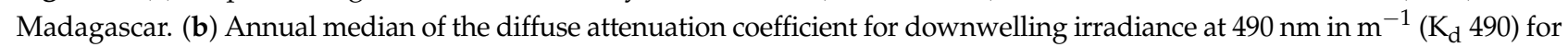
the year 2018 over the wider region (black circle indicated the location of the GRT). Satellite data derived from MODIS-Aqua accessed through OceanColor (https: / oceancolor.gsfc.nasa.gov, accessed on 2 April 2019). Increasing coefficient values indicate higher water turbidity.

\subsection{Sample Collection}

Two antipatharian species, which were the most abundant species at the sites, the bottle-brush-like Cupressopathes abies (Figure 2a) and the whip-like Stichopathes maldivensis (Figure 2b), were sampled. Six colonies of each species were sampled at a $20 \mathrm{~m}$ depth and five colonies of each at a $40 \mathrm{~m}$ depth in November-December 2018 (permit no. 089/19/MESipReS). Colony height ranged between 25 and $35 \mathrm{~cm}$ for C. abies and 200 and $250 \mathrm{~cm}$ in height for S. maldivensis. It has been shown that Symbiodiniaceae abundance and clade can vary at the intra-colony level [24]; therefore, three samples 3-4 cm long were taken from each colony at the top, the middle and the base, making a total of 66 samples from 22 separate colonies. Half of every sample was preserved in $100 \%$ ethanol for subsequent molecular analysis. The other half was fixed in 3\% glutaraldehyde buffered with $0.1 \mathrm{M}$ sodium cacodylate before rinsing and storing them in $70 \%$ ethanol for later morphological study. Due to the minute size of their polyps ( $\sim 0.7 \mathrm{~mm}$, Figure $2 \mathrm{a})$, prior to fixation, samples of $C$. abies were placed in a $5 \mathrm{~g} / \mathrm{L}$ magnesium chloride solution buffered in filtered sea water in order to relax the polyps and tentacles so as to facilitate further observation. 

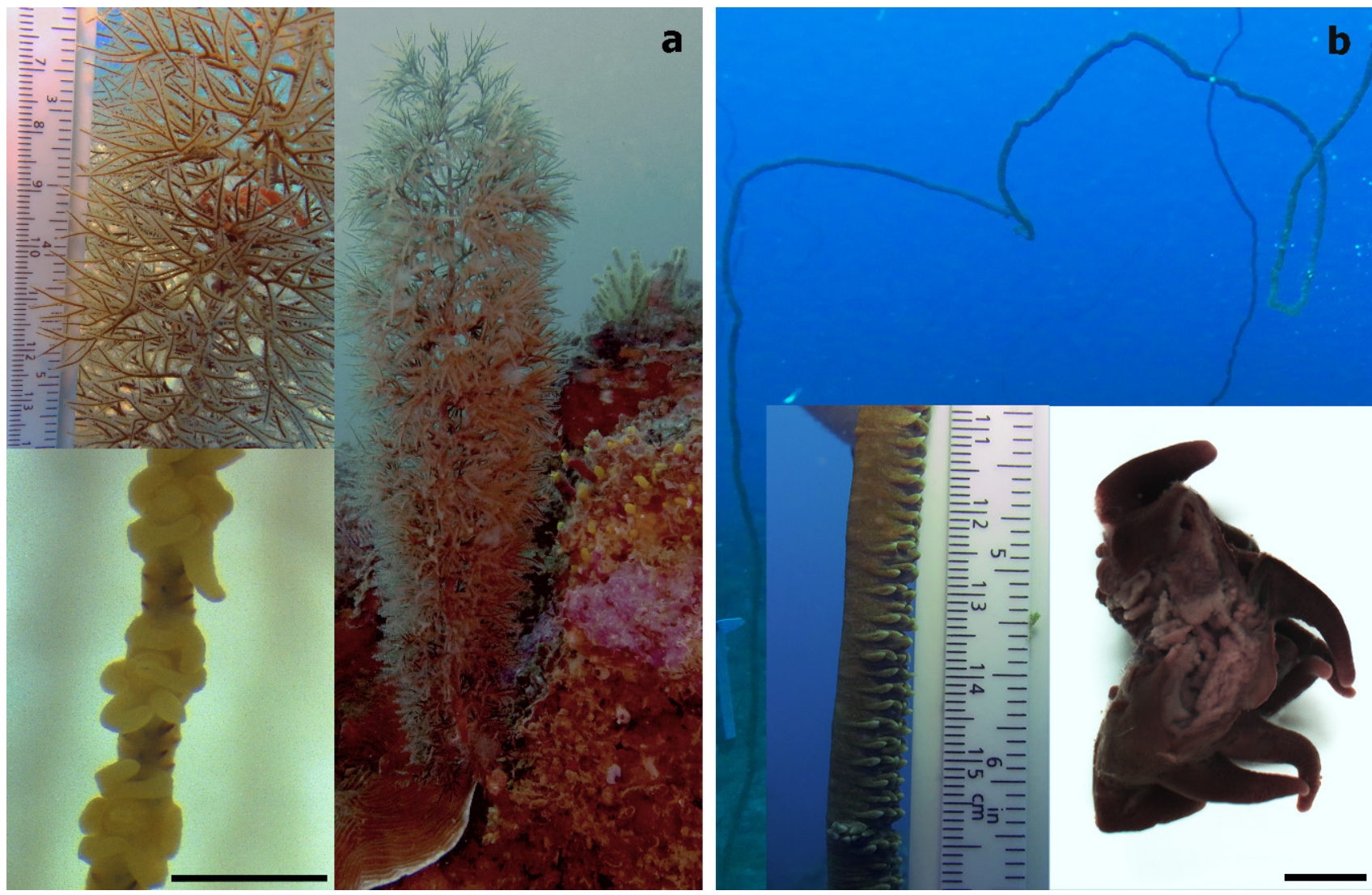

Figure 2. (a) The bottle-brush-like Cupressopathes abies and (b) the whip-like Stichopathes maldivensis, with an image showing a section of two individual polyps in the bottom right corner. Scale bars of polyp images $=1 \mathrm{~mm}$.

\subsection{Isolation of Symbiodiniaceae Cells}

From each of the 66 samples preserved in $100 \%$ ethanol, $1 \mathrm{~cm}$ fragments were cut, amounting to an estimated $20 \mathrm{mg}$ of tissue for both species. Each fragment included about two polyps in the case of $S$. maldivensis or about eight polyps in the case of $C$. abies. Following a method adapted from [45] to isolate Symbiodiniaceae cells from cnidarians, samples were placed in $1.5 \mathrm{~mL}$ tubes with $500 \mu \mathrm{L}$ of a $2 \mathrm{M}$ sodium hydroxide solution. These were incubated at $37{ }^{\circ} \mathrm{C}$ for $1 \mathrm{~h}$ and then vortexed at a medium speed (using an Analitik Jena Tmix homogenizer) at the same temperature for about $2 \mathrm{~h}$ until complete lysis of the antipatharian tissues had occurred. The tubes were then centrifuged at $8000 \mathrm{rpm}$ for $3 \mathrm{~min}$, and the supernatant was discarded, then the pellet was resuspended in ultra-pure (Milli-Q) water and vortexed. One drop of lugol was added to the solution to re-stain the cells that might have lost pigments after preservation. About $8 \mu \mathrm{L}$ of the pellet in $7 \mu \mathrm{L}$ was used per chamber. Counts of visible Symbiodiniaceae were undertaken using a glass haemocytometer and an Axioscope A1 (Zeiss) light microscope. The number of the microalgae cells in all nine squares $\left(1 \mathrm{~mm}^{2}\right.$ each) of four counting chambers per sample was counted in order to estimate the density of cells per $\mu \mathrm{L}$. To corroborate the efficiency of the procedure, the isolation protocol was also carried out on fresh and preserved (100\% ethanol) samples of the scleractinian coral Seriatopora hystrix (Figure 3). To test for differences in microalgae density between antipatharian species, depths and colony region (top, middle or bottom part), a quasi-Poisson generalised linear model (GLM) was fitted using the 'stats' package in R [46]. The power to detect differences between depths was calculated using the function 'power.t.test' in the same 'stats' package. 

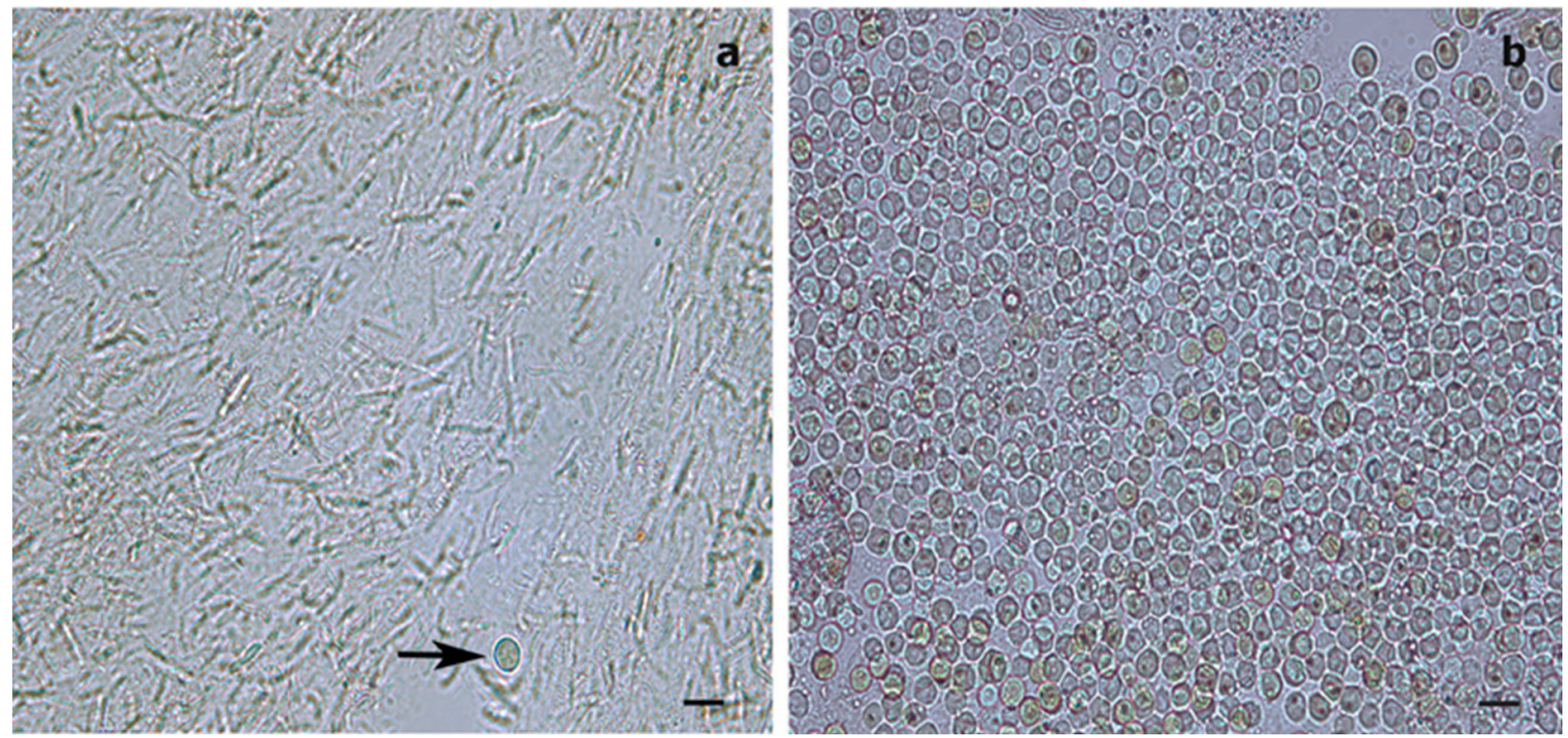

Figure 3. Light microscopy images of Symbiodiniaceae-like extracts obtained through the sodium hydroxide isolation method. (a) Extract from the antipatharian Cupressopathes abies showing only one Symbiodiniaceae-like cell (arrow) but abundant cnidocytes. (b) Extract from the scleractinian Seriatopora hystrix showing numerous Symbiodiniaceae-like cells, corroborating the efficiency of the isolation method. Scale bars $=10 \mu \mathrm{m}$.

\subsection{Microscopy}

\section{(a) Histology}

Histological sections were taken to determine the presence and location of Symbiodiniaceae cells within the coral's tissue. About $1.5 \mathrm{~cm}$ of each sample was dehydrated using increasing concentrations of ethanol, then soaked in butanol at $60^{\circ} \mathrm{C}$ for $24 \mathrm{~h}$. These samples were then embedded in liquid paraffin. Serial sections of $7 \mu \mathrm{m}$ were cut using a Microm HM 340E (Zeiss) microtome and stained with a Masson's trichrome. The sections were observed and photographed using an Axioscope A1 (Zeiss) light microscope and Axiocam 305 camera.

(b) Transmission electron microscope (TEM)

For each species, sub-sample sections were made from the samples of the top, middle and bottom part of one colony from a $20 \mathrm{~m}$ depth and one colony from a $40 \mathrm{~m}$ depth. For S. maldivensis, due to the large size of the polyps ( $\sim \mathrm{mm}$, Figure $2 \mathrm{~b})$, sections of the tentacles and of the oral cone were analysed separately, making a total of 18 sub-samples in all. These sections, each about $1 \mathrm{~cm}$ long, were post-fixed for $1 \mathrm{~h}$ at room temperature with $1 \%$ osmium tetroxide in a $0.1 \mathrm{M}$ sodium cacodylate and $2.3 \%$ sodium chloride buffer. They were rinsed several times in the same buffer and dehydrated in an increasing concentration series of ethanol. Samples were then placed in Spurr resin overnight before polymerisation at $70{ }^{\circ} \mathrm{C}$ for $24 \mathrm{~h}$. Then ultrathin sections of $50-70 \mathrm{~nm}$ were cut on a Leica Ultracut (UCT) microtome equipped with a diamond knife and collected on formvar-coated copper grids. These were stained with uranyl acetate and lead citrate and observed with an LEO 906E (Zeiss) transmission electron microscope.

(c) Scanning electron microscope (SEM)

For each species, the samples corresponding to the middle sections of one colony from a $20 \mathrm{~m}$ depth and one from a $40 \mathrm{~m}$ depth (each about $1.5 \mathrm{~cm}$ long) were studied under a scanning electron microscope (SEM). The four samples stored in $70 \%$ ethanol were then dehydrated for TEM analysis. Sub-samples were also made in order to be frozen with liquid nitrogen before being cut randomly. The eight sub-samples were dried in a critical-point dryer using $\mathrm{CO}_{2}$ as the transition fluid (Agar Scientific Ltd.) before being mounted on 
aluminium stubs and coated with gold in a JFC-1100E (JEOL) sputter coater. These samples were observed and photographed with a JSM-7200F (JEOL) scanning electron microscope.

\subsection{Molecular Analyses}

Middle parts of the colonies of both species and from both depths (preserved in $100 \%$ ethanol) were cut into $8 \mathrm{~mm}$ fragments. The total genomic DNA of each sample was extracted using QIAGEN DNeasy Blood \& Tissue Kit using the manufacturer's protocol. The concentration and quality of DNA were examined at $260 \mathrm{~nm}$ using a spectrophotometer (DeNovix). The internal transcribed spacer-2 (ITS2) region of the dinoflagellate ribosomal DNA (rDNA) was amplified using the primers ITS-DINO (5' GTGAATTGCAGAACTCCGTG 3') and ITS2-REV2 (5' CCTCCGCTTACTTATATGCTT $\left.3^{\prime}\right)$ following conditions described in [47]. A second set of primers, SYM_VAR_5.8S2 (5' GAATTGCAGAACTCCGTGAACC $3^{\prime}$ ) and SYM_VAR_REV (5' CGGGTTCWCTTGTYTGACTTCATGC $\left.3^{\prime}\right)$, were used for PCR amplification of the ITS2 region, following the protocol described in [48]. This second set of primers was used in addition to the former because it has been found to perform better than other ITS2 primer sets tested on a range of Symbiodiniaceae ITS2 rDNA [48]. The presence of amplicons was checked in a $2 \%$ agarose gel in Tris-Borate-EDTA buffer. A DNA extract from a scleractinian coral of the genus Acropora from Toliara (Madagascar) was used as positive control.

\section{Results}

\subsection{Dinoflagellate Cells Count}

The isolation of Symbiodiniaceae-like cells with sodium hydroxide should have enabled efficient isolation of the microalgal cells if present within the coral tissues and also isolated cnidocytes (Figure 3). For both antipatharian species and both depths (all 66 samples), dinoflagellate cell density ranged between $0-4$ cells $\mathrm{mm}^{-3}$. Microalgae density was different between the two species $(t=2.36, p=0.029$; Table 1$)$, with a mean density of $0.037 \pm 0.013$ cells $\mathrm{mm}^{-3}$ (mean \pm SE) for C. abies and $0.121 \pm 0.034$ cells $\mathrm{mm}^{-3}$ for S. maldivensis. The mean density difference between the two species was 0.084 cells $\mathrm{mm}^{-3}$ regardless of the depth. No significant difference was detected based on the region of the colony using the quasi-Poisson GLM; therefore, the factor 'region' was removed from the model (the average dinoflagellate cell density from the three regions of each colony was calculated to obtain a mean cell density per colony for further analyses). No significant difference was detected in Symbiodiniaceae-like density between depths $(t=-1.577$, $p=0.131$; Table 1). However, the statistical power to detect a significant difference in cell density between depths for each species was limited. The results of a power analysis showed a low power of 0.26 (Type II error rate $74 \%$ ) for S. maldivensis and 0.06 (Type II error rate $94 \%$ ) for C. abies to detect differences between depths.

Table 1. Results of the quasi-Poisson GLM test for differences between species and depths. The intercept represents C. abies dinoflagellate cell density. Significant $p$-value $(p<0.05)$ are shown in bold.

\begin{tabular}{lllll}
\hline Factor & Estimate & Standard Error & $\boldsymbol{t}$-Value & $\boldsymbol{p}$-Value \\
\hline Intercept & -2.27 & 0.74 & -3.08 & $\mathbf{0 . 0 0 6}$ \\
\hline S. maldivensis & 1.16 & 0.49 & 2.36 & $\mathbf{0 . 0 2 9}$ \\
\hline Depth & -0.04 & 0.02 & -1.58 & 0.131 \\
\hline
\end{tabular}

\subsection{Morphological Analyses}

Histological sections could only be produced for the S. maldivensis samples. Symbiodiniaceae-like cells could be observed in both the polyps and the gastrovascular gastrodermis of the sections examined (Figure 4). From most paraffin blocks containing samples of $C$. abies, sections of the tentacles and oral cone were not obtained because there is only a thin layer of tissue surrounding the skeleton, but cells likely to be Symbiodiniaceae could not be detected in the few successful sections that were made. Ultrastructural 
(TEM) observations were possible for all 18 samples examined from the two species, but no Symbiodiniaceae-like cells could be identified in any of them. Mucous cells, zymogen granules, and a large number of cnidocytes, including spirocysts and b-mastigophores were evident (Figure 5). On SEM examination, round cells of different sizes $(3-10 \mu \mathrm{m})$ were observed, among which the larger round cells inside the gastrodermis of the polyp gastrovascular cavity $(\sim 8 \mu \mathrm{m}$; Figure $6 \mathrm{a})$ could be dinoflagellates cells. More abundant were smaller round cells $(3-4 \mu \mathrm{m})$, which are likely to be the vesicular mucous cells also observed on the ultrastructural analysis (Figure 6b).
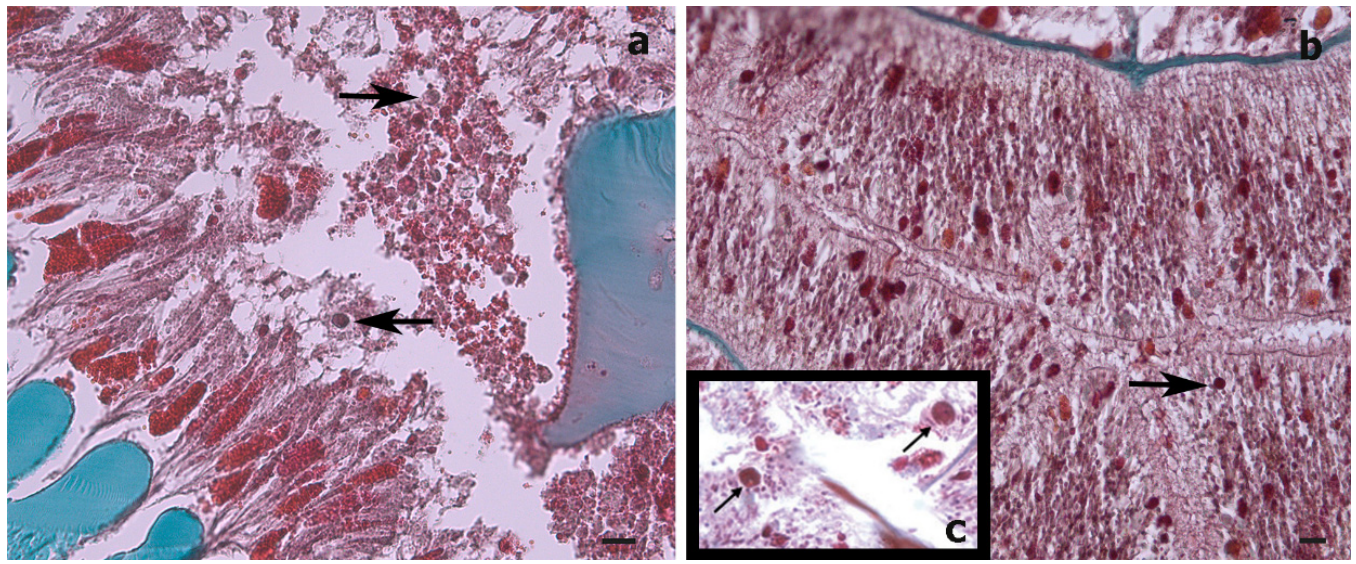

Figure 4. Histological cross-sections of a Stichopathes maldivensis polyp. Symbiodiniaceae-like cells (arrows) are observed in the gastrodermis of the gastrovascular cavity (a) and in the gastrodermis of a lateral tentacle (b). (c) Inset for comparison is an image from Wagner et al. ([34], Figure 2c) in which Symbiodiniaceae cells were identified through histological examination and molecular analysis. Scale bars $=20 \mu \mathrm{m}$.

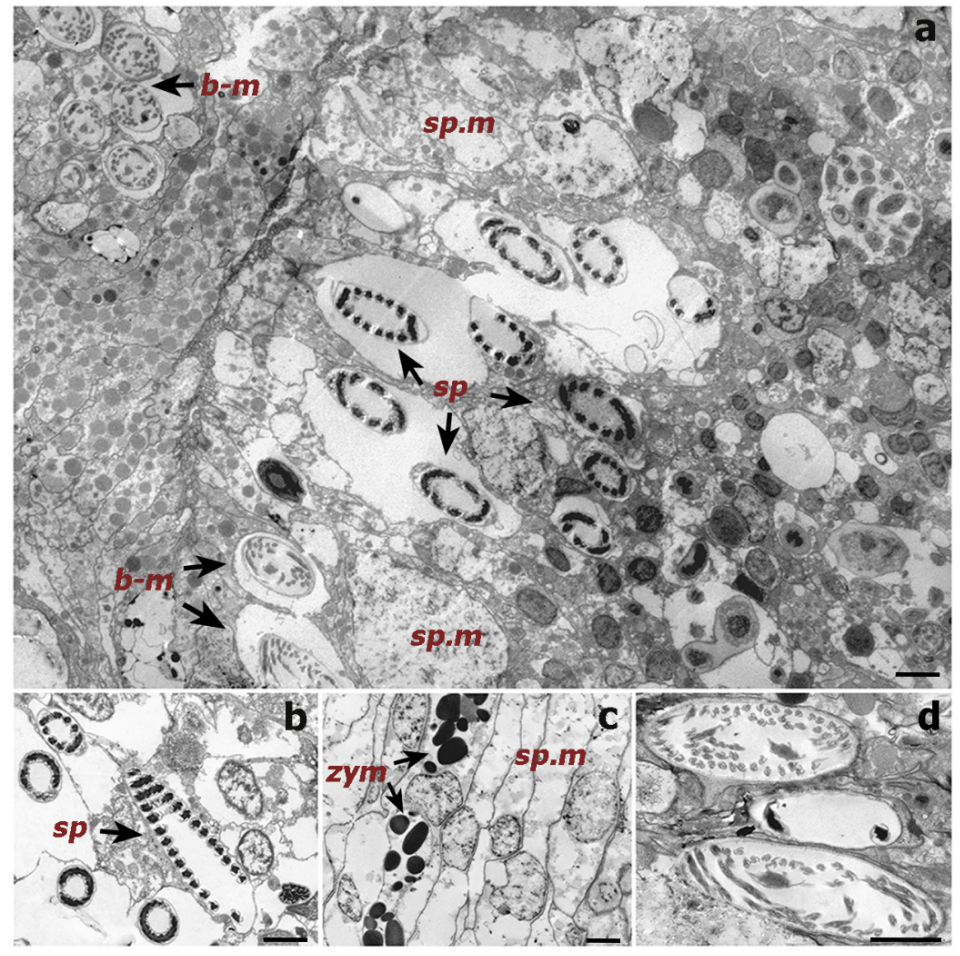

Figure 5. Transmission electron microscope (TEM) images of a cross-section of a Cupressopathes abies polyp tentacle. (a) Ultrastructural view of numerous cnidocytes, including: spirocysts (sp) and b-mastigophores (b-m), as well as spumous mucous cells (sp.m). (b) Longitudinal section of mature spirocysts (sp). (c) Close view of zymogen granules (zym) and spumous mucous cells (sp.m) inside the gastrodermis. (d) Cross-section of mature b-mastigophores. Scale bars $=2 \mu \mathrm{m}$. 

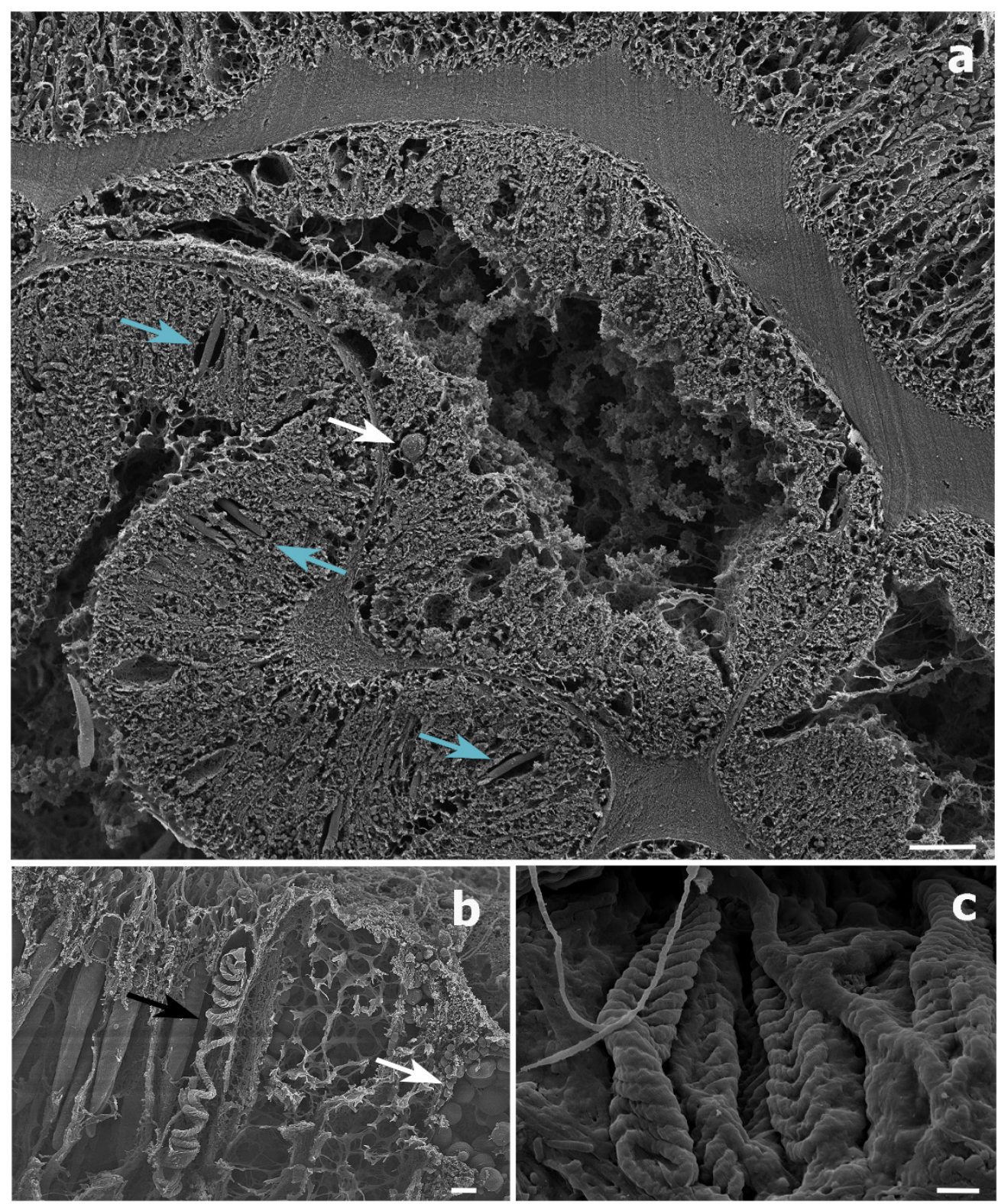

Figure 6. Scanning electron microscope (SEM) images of a Stichopathes maldivensis polyp. (a) A round potentially dinoflagellate-cell of about $8 \mu \mathrm{m}$ inside the gastrodermis of the polyp gastrovascular cavity (white arrow). Numerous b-mastigophores can be observed in the ectoderm (blue arrows). (b) Smaller round cells (3-4 $\mu \mathrm{m}$ ) that are likely to be mucous cells (white arrow) in the polyp ectoderm. The image also shows several b-mastigophores aligned among which one has a broken capsule which exposes the cnidocyte tubule (black arrow). (c) Closer view of spirocysts in a polyp tentacle ectoderm. Scale bars: $\mathrm{a}=10 \mu \mathrm{m}, \mathrm{b}=2 \mu \mathrm{m}, \mathrm{c}=1 \mu \mathrm{m}$.

\subsection{Symbiodiniaceae Molecular Analysis}

No ITS2 sequences of Symbiodiniaceae were successfully amplified from any of the antipatharian DNA extractions. However, the positive control (scleractinian coral DNA extraction) did produce a band on the agarose gel, implying that the method was being used correctly. This was the case for both sets of primers used.

\section{Discussion}

\subsection{Overall Analysis Results}

Despite photosymbiosis being evolutionarily conserved within most lineages in the subclass Hexacorallia [38], an endosymbiotic association between antipatharians and 
Symbiodiniaceae has not been clearly established. High densities of dinoflagellates $\left(\sim 10^{7}\right.$ cells $\left.\mathrm{cm}^{-2}\right)$ were found in three whip-like colonies (Cirrhipathes sp.) [37]. Therefore, it was considered that a study involving a higher number of samples was required in order to assess the microalgal presence and estimate their densities in a greater number of samples from more species and to identify possible patterns regarding species, colony morphology and depth. The present study showed either none or only very low densities $\left(0-4\right.$ cells $\left.\mathrm{mm}^{-3}\right)$ of Symbiodiniaceae-like cells in both the whip-like S. maldivensis and the bushy $C$. abies, both on shallow and on mesophotic reefs. These new findings align with both previous historical observations and more subsequent studies that found few, if any, endosymbiotic algae in antipatharians [32-36]. These studies-ours included-evidence that high abundances of dinoflagellates within antipatharians is not a common finding. Considering the relevance of antipatharians for habitat provision on reefs and the increasing extent of mass bleaching events affecting scleractinian corals, the possibility of most antipatharians being exempt from this threat warrants further investigation.

While, in our study, the dinoflagellates' identity could not be determined by molecular analysis, the Symbiodiniaceae-like cells observed in the histological sections of the whip-like S. maldivensis closely resembled those described in the other two studies [34,37] (Figure 4). For future histological examination of antipatharians, where the tissue cannot be separated from the skeleton (such as $C$. abies), we suggest experimenting with softening the skeletons with a lytic polysaccharide monooxygenases (LPMOs) treatment [49]. We applied the same sodium hydroxide isolation protocol—a protocol found to be effective for scleractinians and other cnidarians [45] — to a scleractinian coral fragment, and it was clear that the cells obtained were Symbiodiniaceae (Figure 3). Nevertheless, it is probably safer to refer to the cells in our antipatharian samples only as being Symbiodiniaceae-like.

In the present study, Symbiodiniaceae-like cells were observed in the SEM and histological examination located inside the coral gastrodermis of S. maldivensis (Figures 5 and 6). This suggests an endosymbiotic association, which was also suggested from histological sections analysis and from ultrastructural analysis [34,37]. The fact that no Symbiodiniaceae ITS2 sequences were amplified from the DNA extractions in this study seems most likely due to the extremely low density of dinoflagellates. In the two studies where identification was possible, different genera (Cladocopium, Gerakladium and Durusdinium) were reported to be associated with different antipatharian species [34,37]. Such plasticity, even at the intra-colony level, has also been evidenced in more recent studies on scleractinian corals and is believed to be environmentally driven [24]. Moreover, there is evidence to suggest that the same Symbiodiniaceae species may be mutualistic in one host context but opportunistic in another [50]. Therefore, the identity of the dinoflagellates alone is insufficient to determine the type of symbiosis. Further studies will be necessary to determine the nature of the association between Symbiodiniaceae and antipatharians, particularly in cases where microalgae abundance is high, as in [37].

\subsection{Dinoflagellate Density Difference between Species}

Density estimates showed that colonies of the whip-like S. maldivensis had significantly more Symbiodiniaceae-like cells within their tissues compared to C. abies regardless of depth ( 0.084 mean cells $\mathrm{mm}^{-3}$ density difference, Table 1$)$. However, due to the very low densities of dinoflagellates observed in both species, it is difficult to determine the biological significance of this difference. To date, a single study examined multiple species (14) and different colony morphologies (both whip-like and branching) [34]. The branching species, Antipathes griggi, recorded the highest density $\left(0-92\right.$ cells $\left.\mathrm{mm}^{-3}\right)$, although microalgal cells were observed in only one of the eight colonies of this species examined. Variation in density was also observed in our study, which is the first to have examined several colonies of the same species from two contrasting depths. Of the eleven colonies of each species, only four colonies of $C$. abies and seven of $S$. maldivensis were observed to contain microalgae. On the other hand, no differences were found between the three different regions (top, middle and base) within any single colony. This suggests that the intra-specific 
variability recorded in [34], as well as ourselves, is unlikely to be caused by variations in the microalgal cell density between different parts of the colonies. From this limited information, it seems plausible that other factors, rather than species or morphology, might account for the greater numbers of microalgal cells found in some antipatharian colonies.

\subsection{Dinoflagellate Density Difference between Depths}

Contrary to expectation, no statistically significant difference in dinoflagellate density was found between shallow and mesophotic depths, although the mean dinoflagellates density at $20 \mathrm{~m}$ depth was greater than at $40 \mathrm{~m}$ depth in both species (the mean differences between depths being 0.200 and 0.016 cells $\mathrm{mm}^{-3}$ for S. maldivensis and C. abies, respectively). Differences in microalgae density can be inferred from previous studies. For instance, among the 14 samples from different colonies of $A$. griggi from Hawaii for which the cell density was reported, the highest densities were from the two colonies sampled on shallow reefs [34]. The samples of Cirrhipathes collected in Bunaken, Indonesia, were from two different depths $(15$ and $38 \mathrm{~m})$ [37]. While it was not reported whether there were any differences in Symbiodiniaceae density related to depth, the $K_{d} 490$ (proxy of turbidity) values at $15 \mathrm{~m}$ and $38 \mathrm{~m}$ depth in Bunaken have been estimated to be very similar [50]. In Toliara, Madagascar, where the $K_{d} 490$ values indicate high turbidity (Figure 1b) due to sedimentation derived from river runoff, light penetration at a $40 \mathrm{~m}$ depth is likely to be considerably reduced (as was noticeable during field work). However, it is not inevitable that higher densities of Symbiodiniaceae should be found in association with antipatharians in shallower water since it is believed that the uptake of dinoflagellates in the coral-algae symbiotic association can be controlled by the coral host [25,31]. More studies on antipatharian colonies exposed to higher radiations are therefore necessary to assess the significance of high densities of dinoflagellates in antipatharians (assuming they occur), and to understand the mechanism behind the association.

\section{Conclusions}

This study represents a broader integrative approach to investigating the presence and density of Symbiodiniaceae in antipatharians than has been used in previous studies. We combined microalgal cell extraction, histological examination and transmission and scanning microscopy with attempted sequencing of DNA samples. We found that Symbiodiniaceae-like cells were present within some of the antipatharian samples of $S$. maldivensis and C. abies from SW Madagascar, although the overall density of macroalgae cells in both antipatharian species from both shallow and mesophotic reefs was very low. This low density aligns with the majority of previous findings, indicating that high Symbiodiniaceae densities are not characteristic of antipatharians. These findings are significant in the context of extensive 'coral bleaching' events threatening the integrity of coral reefs, suggesting that most antipatharians are likely to be less prone to this phenomenon. Nonetheless, considering that high densities of dinoflagellates have been documented in three colonies of one antipatharian species, more studies are desirable to understand the mechanism and implications of the coral-algae relationship within this coral taxon. Studies on other effects that climate change might have on antipatharians are also desirable.

Author Contributions: Conceptualization, E.G. and I.E.; Data curation, E.G., M.G. and J.R.; Formal analysis, E.G.; Funding acquisition, I.E., P.D. and L.T.; Methodology, E.G., I.E. and L.T.; Writingoriginal draft, E.G.; Writing-review and editing, I.E. All authors have read and agreed to the published version of the manuscript.

Funding: This research was funded by the Fonds National de la Recherche Scientifique, Belgium (no. PDR T0083.18), under the 'Conservation Biology of Black Corals' research project co-directed by the University of Mons, the University of Liège, and the Free University of Brussels, in Belgium.

Informed Consent Statement: Not applicable.

Data Availability Statement: The dataset generated for this study are available on request to the corresponding author. No sequence data was generated on this study. 
Acknowledgments: We thank: All the members at the Marine Organisms Biology and Biomimetics (BOMB) Laboratory in Belgium for their assistance during sample analyses. Nicolas Sturaro, University of Liege, for help with sample collection. Members at the University of Toliara, Madagascar, for support during field work. Liz Tynan, James Cook University, for editorial comments and Rupert Ormond, Heriot-Watt University, for editorial review. Figure 1b created on R (R Team 2019) with an adapted script provided by J.C. Fischer, University of Bayreuth, and A. Wiefels, University of Reunion Island. We are very grateful to Dennis Opresko, Smithsonian Institute, for continuous support.

Conflicts of Interest: We declare that the research was conducted in the absence of any commercial or financial relationships that could be construed as a potential conflict of interest.

\section{References}

1. Rogers, C.S. The effect of shading on coral reef structure and function. J. Exp. Mar. Biol. Ecol. 1979, 41, 269-288. [CrossRef]

2. Hinderstein, L.M.; Marr, J.C.A.; Martinez, F.A.; Dowgiallo, M.J.; Puglise, K.A.; Pyle, R.L.; Zawada, D.G.; Appeldoorn, R. Theme section on "Mesophotic Coral Ecosystems: Characterization, Ecology, and Management". Coral Reefs 2010, 29, 247-251. [CrossRef]

3. Pyle, R.L.; Copus, J.M. Mesophotic Coral Ecosystems: Introduction and Overview. Coral Reefs World 2019, 39, $1469-1482$.

4. Baker, E.K.; Puglise, K.A.; Harris, P.T. Mesophotic Coral Ecosystems-A Lifeboat for Coral Reefs? The United Nations Environment Programme and GRID-Arendal: Arendal, Norway, 2016.

5. Gress, E.; Arroyo-Gerez, M.J.; Wright, G.; Andradi-Brown, D.A. Assessing mesophotic coral ecosystems inside and outside a Caribbean marine protected area. R. Soc. Open Sci. 2018, 5, 180835. [CrossRef]

6. Brugler, M.R.; Opresko, D.M.; France, S.C. The evolutionary history of the order Antipatharia (Cnidaria: Anthozoa: Hexacorallia) as inferred from mitochondrial and nuclear DNA: Implications for black coral taxonomy and systematics. Zool. J. Linn. Soc. 2013, 169, 312-361. [CrossRef]

7. Opresko, D.M. New species of black corals (Cnidaria: Anthozoa: Antipatharia) from the New Zealand region, part 2. N. Z. J. Zool. 2019, 47, 149-186. [CrossRef]

8. Grigg, R.W. Ecological studies of Black Coral in Hawaii. Pac. Sci. 1965, 19, 244-260.

9. Wagner, D.; Luck, D.G.; Toonen, R.J. The Biology and Ecology of Black Corals (Cnidaria: Anthozoa: Hexacorallia: Antipatharia). Adv. Mar. Biol. 2012, 63, 67-132. [CrossRef]

10. Goldberg, W.M. Chemical changes accompanying maturation of the connective tissue skeletons of gorgonian and antipatharian corals. Mar. Biol. 1978, 49, 203-210. [CrossRef]

11. Goldberg, W.M.; Hopkins, T.L.; Holl, S.M.; Schaefer, J.; Kramer, K.J.; Morgan, T.D.; Kim, K. Chemical composition of the sclerotized black coral skeleton (Coelenterata: Antipatharia): A comparison of two species. Comp. Biochem. Physiol. Part B Biochem. 1994, 107, 633-643. [CrossRef]

12. Bo, M.; Montgomery, A.D.; Opresko, D.M.; Wagner, D.; Bavestrello, G. Antipatharians of the Mesophotic Zone: Four Case Studies. In Coral Reefs of the World; Springer: Singapore, 2019; pp. 683-708.

13. Tazioli, S.; Bo, M.; Boyer, M.; Boyer, M.; Rotinsulu, H.; Bavestrello, G. Ecological observations of some common antipatharian corals in the marine park of Bunaken (North Sulawesi, Indonesia). Zool. Stud. 2007, 46, 227-241.

14. Suarez, H.N.; Dy, D.T.; Violanda, R.R. Density of associated macrofauna of black corals (Anthozoa: Antipatharia) in Jagna, Bohol, central Philippines. Philipp. J. Sci. 2015, 144, 107-115.

15. Parrish, F.A.; Abernathy, K.; Marshall, G.J.; Buhleier, B.M. Hawaiian monk seals (Monachus schauinslandi) foraging in deep-water coral beds. Mar. Mammal. Sci. 2002, 18, 244-258. [CrossRef]

16. Boland, R.C.; Parrish, F.A. Description of Fish Assemblages in the Black Coral Beds off Lahaina, Maui, Hawai'i. Pac. Sci 2005, 59, 411-420. [CrossRef]

17. Bruckner, A.W. Advances in Management of Precious Corals to Address Unsustainable and Destructive Harvest Techniques. In The Cnidaria, Past, Present and Future, 1st ed.; Goffredo, S., Dubinsky, Z., Eds.; Springer International Publishing: Cham, Switzerland, 2016; pp. 747-786.

18. Terrana, L.; Lepoint, G.; Eeckhaut, I. Assessing trophic relationships between shallow-water black corals (Antipatharia) and their symbionts using stable isotopes. Belg. J. Zool. 2019, 149, 107-121. [CrossRef]

19. Baker, A.C.; Glynn, P.W.; Riegl, B. Climate change and coral reef bleaching: An ecological assessment of long-term impacts, recovery trends and future outlook. Estuar. Coast Shelf. Sci. 2008, 80, 435-471. [CrossRef]

20. Hughes, T.P.; Kerry, J.T.; Simpson, T. Large-scale bleaching of corals on the Great Barrier Reef. Ecology 2018, 99, 501. [CrossRef]

21. Bongaerts, P.; Smith, T.B. Beyond the "Deep Reef Refuge" Hypothesis: A Conceptual Framework to Characterize Persistence at Depth; Springer: Cham, Switzerland, 2019; pp. 881-895.

22. Fisher, R.; Bessell-Browne, P.; Jones, R. Synergistic and antagonistic impacts of suspended sediments and thermal stress on corals. Nat. Commun. 2019, 10, 2346. [CrossRef]

23. Lajeunesse, T.C.; Parkinson, J.; Gabrielson, P.W.; Jeong, H.J.; Reimer, J.D.; Voolstra, C.R.; Santos, S.R. Systematic Revision of Symbiodiniaceae Highlights the Antiquity and Diversity of Coral Endosymbionts. Curr. Biol. 2018, 28, 2570-2580.e6. [CrossRef] 
24. Meistertzheim, A.-L.; Pochon, X.; Wood, S.A.; Ghiglione, J.-F.; Hédouin, L. Development of a quantitative PCR-high-resolution melting assay for absolute measurement of coral-Symbiodiniaceae associations and its application to investigating variability at three spatial scales. Mar. Biol. 2019, 166, 13. [CrossRef]

25. Davy, S.K.; Allemand, D.; Weis, V. Cell Biology of Cnidarian-Dinoflagellate Symbiosis. Microbiol. Mol. Biol Rev. 2012, 76, $229-261$. [CrossRef]

26. Brodersen, K.E.; Lichtenberg, M.; Ralph, P.; Kühl, M.; Wangpraseurt, D. Radiative energy budget reveals high photosynthetic efficiency in symbiont-bearing corals. J. R. Soc. Interface 2014, 11, 20130997. [CrossRef]

27. Roth, M.S. The engine of the reef: Photobiology of the coral-algal symbiosis. Front. Microbiol. 2014, 5, 422. [CrossRef]

28. Roth, M.; Padilla-Gamiño, J.; Pochon, X.; Bidigare, R.; Gates, R.; Smith, C.; Spalding, H. Fluorescent proteins in dominant mesophotic reef-building corals. Mar. Ecol. Prog. Ser. 2015, 521, 63-79. [CrossRef]

29. Weis, V.M. Cellular mechanisms of Cnidarian bleaching: Stress causes the collapse of symbiosis. J. Exp. Biol. 2008, 211, 3059-3066. [CrossRef]

30. Lesser, M.P. Oxidative stress in marine environments: Biochemistry and physiological ecology. Annu. Rev. Physiol. 2006, 68, 253-278. [CrossRef]

31. Barott, K.L.; Venn, A.A.; Perez, S.O.; Tambutté, S.; Tresguerres, M. Coral host cells acidify symbiotic algal microenvironment to promote photosynthesis. Proc. Natl. Acad. Sci. USA 2015, 112, 607-612. [CrossRef]

32. Brook, G. Report on the Antipatharia collected by HMS Challenger during the years 1873-1876. Report on the Scientific Results of the Voyage of HMS Challenger During the Years 1873-76. Zoology 1889, 32, 1-222. [CrossRef]

33. van Pesch, A.J. The Antipatharia of the Siboga Expedition. Siboga Exped. Monogr. 1914, 17, 1-258.

34. Wagner, D.; Pochon, X.; Irwin, L.; Toonen, R.; Gates, R.D. Azooxanthellate? Most Hawaiian black corals contain Symbiodinium. Proc. R. Soc. B Biol. Sci. 2010, 278, 1323-1328. [CrossRef]

35. Grigg, R.W. A Contribution to the Biology and Ecology of the Black Coral, Antipathes grandis in Hawai'i. MS Thesis in Zoology, 1964, p. 74. Hawai'i., Honolulu. Available online: http://cn.deziderkostrec.xyz/read/?id=Qv7PHAAACAAJ\&format=pdf\& server=1 (accessed on 2 April 2019).

36. Santiago-Vázquez, L.Z.; Brück, T.B.; Brück, W.M.; Duque-Alarcón, A.P.; McCarthy, P.J.; Kerr, R.G.; Br, T.B. The diversity of the bacterial communities associated with the azooxanthellate hexacoral Cirrhipathes lutkeni. ISME J. 2007, 1, 654-659. [CrossRef]

37. Bo, M.; Baker, A.; Gaino, E.; Wirshing, H.; Scoccia, F.; Bavestrello, G. First description of algal mutualistic endosymbiosis in a black coral (Anthozoa: Antipatharia). Mar. Ecol. Prog. Ser. 2011, 435, 1-11. [CrossRef]

38. McFadden, C.S.; Quattrini, A.M.; Brugler, M.R.; Cowman, P.F.; Dueñas, L.F.; Kitahara, M.V.; A. Paz-García, D.; Reimer, J.D.; Pichon, M. Recherches sur les peuplements à dominance d'anthozoaires dans les récifs coralliens de Tuléar (Madagascar). Atoll Res. Bull. 1978, 222, 1-490.

39. Harris, A.; Manahira, G.; Sheppard, A.; Gouch, C.; Sheppard, C. Demise of Madagascar's once great barrier reef: Changes in coral reef conditions over 40 years. Atoll Res. Bull. 2010, 574, 1-16. [CrossRef]

40. Todinanahary, G.; Terrana, L.; Lavitra, T. First records of illegal harvesting and trading of black corals (Antipatharia) in Madagascar. Madag. Conserv. Dev. 2016, 11, 1-6. [CrossRef]

41. Todinanahary, G.G.; Refoty, M.E.; Terrana, L.; Lavitra, T.; Eeckhaut, I. Previously unlisted scleractinian species recorded from the Great Reef of Toliara, southwest Madagascar. West. Indian Ocean J. Mar. Sci. 2018, 17, 67. [CrossRef]

42. Gudka, M.; Obura, D.; Mwaura, J.; Porter, S.; Yahya, S.; Mabwa, R. Impact of the 3rd Global Coral Bleaching Event on the Western Indian Ocean in 2016; Global Coral Reef Monitoring Network (GCRMN)/Indian Ocean Commission: Port Louis, Mauritius, 2016; p. 67.

43. Zhang, T.; Fell, F. An empirical algorithm for determining the diffuse attenuation coefficient $K_{d}$ in clear and turbid waters from spectral remote sensing reflectance. Limnol. Oceanogr. Methods 2007, 5, 457-462. [CrossRef]

44. Zamoum, T.; Furla, P. Symbiodinium isolation by NaOH treatment. J. Exp. Biol. 2012, 215, 3875-3880. [CrossRef]

45. R Core Team. R: A Language and Environment for Statistical Computing; R Foundation for Statistical Computing: Vienna, Austria, 2019; Available online: https://www.R-project.org/ (accessed on 2 April 2019).

46. Stat, M.; Pochon, X.; Cowie, R.; Gates, R. Specificity in communities of Symbiodinium in corals from Johnston Atoll. Mar. Ecol. Prog. Ser. 2009, 386, 83-96. [CrossRef]

47. Hume, B.C.; Ziegler, M.; Poulain, J.; Pochon, X.; Romac, S.; Boissin, E.; De Vargas, C.; Planes, S.; Wincker, P.; Voolstra, C.R. An improved primer set and amplification protocol with increased specificity and sensitivity targeting the Symbiodinium ITS2 region. PeerJ 2018, 6, e4816. [CrossRef]

48. Mutahir, Z.; Mekasha, S.; Loose, J.S.M.; Abbas, F.; Vaaje-Kolstad, G.; Eijsink, V.G.H.; Forsberg, Z. Characterization and synergistic action of a tetra-modular lytic polysaccharide monooxygenase from Bacillus cereus. FEBS Lett. 2018, 592, 2562-2571. [CrossRef]

49. Pettay, D.T.; Wham, D.C.; Smith, R.T.; Iglesias-Prieto, R.; LaJeunesse, T.C. Microbial invasion of the Caribbean by an Indo-Pacific coral zooxanthella. Proc. Natl. Acad. Sci. USA 2015, 112, 7513-7518. [CrossRef] [PubMed]

50. Holden, H. Characterisation of Optical Water Quality in Bunaken National Marine Park, Indonesia. Singap. J. Trop. Geogr. 2002, 23, 23-36. [CrossRef] 